\title{
Internet User and Income Consumption in an Effort to Empower MSMEs in Indonesia
}

Diah Rusmingsih

(STIE Jaya Negara Tamansiswa Malang)

Sebastiana Viphindrartin

(University of Jember)

\begin{abstract}
This study aims to observe the growth impetus for internet users towards public consumption which further boosts people's income in Indonesia. To achieve this objective, data on internet user behaviour, consumption and GDP per capita were observed. This study uses the Quantitative Threshold Autoregressive method which is used to predict the behaviour of the data so that the relationship behaviour between the data can be seen. The hope is that knowing past behaviour data can be an indicator of decisions that can be taken in the future. All data are secondary data from world banks. We found that Internet users are the total internet users in Indonesia who are able to boost people's income as indicated by GDP per capita. Where the internet users' impulse towards consumption is very strong. This indicates a massive growth in business lines as a result of the Internet revolution in Indonesia, namely trading businesses that involve digital technology.
\end{abstract}

Keywords: Technology, Consumption, Gross Domestic Product Per Capita

\section{Introduction}

Indonesia is a country with a population that includes many in Asia (Chen-Wishart \& Vogenauer,2020). The large population indicates the size of domestic consumption which is quite large. With large domestic consumption, it provides opportunities for the MSME sector to grow and develop because of the large number of consumers, namely the Indonesian population.

The growth of MSMEs, where in Indonesia the number of MSMEs is very large, has an impact on increasing income as indicated by GDP per capita (Dewi \& Mahendrawathi,2019). This is because the growth of MSMEs indicates an increase in the income of MSME players so that they can grow and develop.The increase in income that is driven by the MSME sector will rotate within the country. With growing MSMEs, an increase in the supply of domestic goods and services can grow so that there will be an increase in domestic production and to absorb domestic production growth, domestic marketing is needed.

Based on data from the world bank, internet users in Indonesia continue to grow, up five times in the last 10 years. From 25 million people in 2008, it increased to 143 million people. The growth of 
internet users in Indonesia is inseparable from the widespread ownership of cellular phones. The Internet is a productive and affordable tool for Indonesians to sell and buy goods produced by MSMEs. The birth of various e-commerce in Indonesia supports internet-based marketing. Internet inclusion in Indonesia is also growing. Based on data from the world bank, internet users in Indonesia are growing every year. Following is the growth of internet users in Indonesia from 2000 to 2019.

Figure 1. Internet User In Indonesia 2000-2019

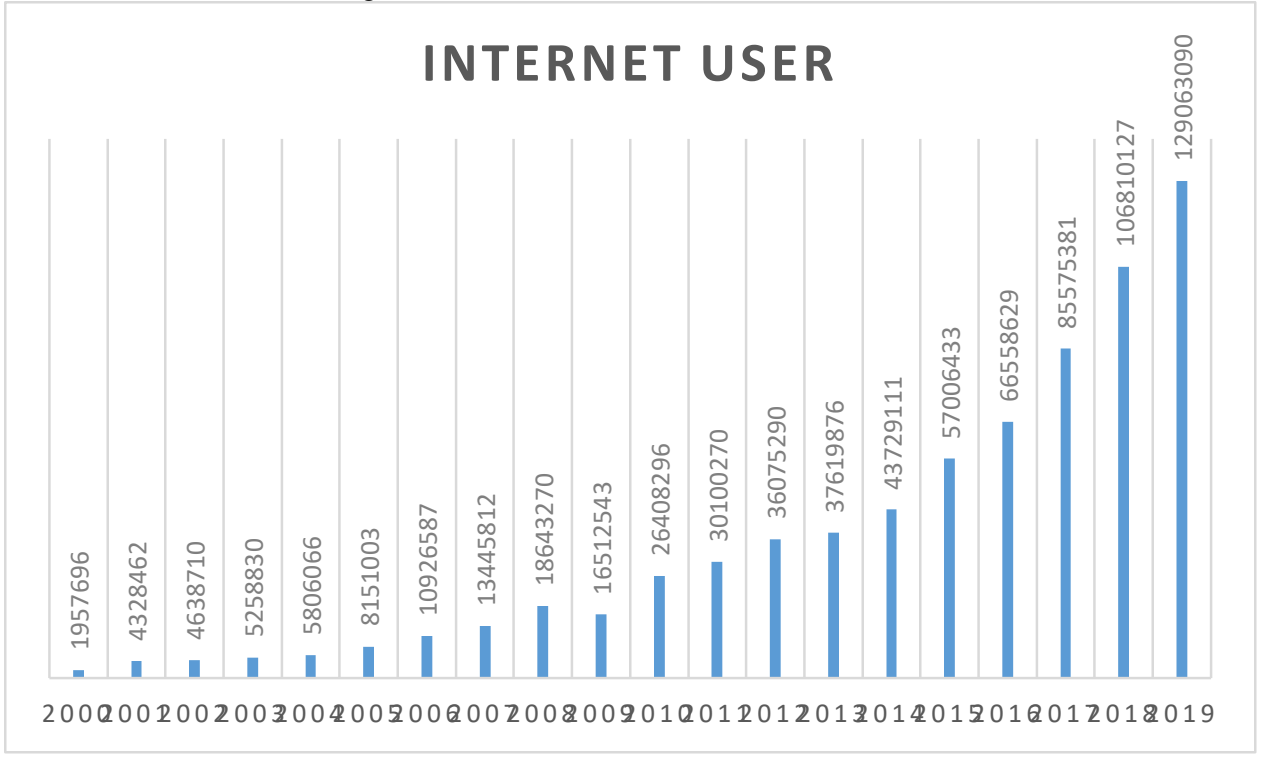

Source : World Bank Data Compiled

Based on graph 1. Internet users are growing massively and this can be seen in Figure 1. Internet users continue to grow every year in Indonesia. The growth of internet users is a big opportunity in the development of digital marketing-based MSMEs. The increase in internet users shows that the inclusion of internet technology is getting better in Indonesia. This was followed by the online shopping trend. Of course, people who have MSME businesses can promote and sell their products online via the internet. The emergence of various marketplaces makes it easier for MSMEs to sell their products.

The internet also facilitates the ease of transactions, including the ease of buying and selling. This ease of transaction ultimately increases consumption (Liu et al,2020). Increased consumption indicates an increase in demand which encourages producers to increase production. An increase in production and an increase in sales creates an increase in income represented by GDP per capita.

This study aims to see consumption incentives through the growth of internet users on people's income growth using an indicator, namely GDP per capita.

\section{Literature Review}

Human civilization has evolved from the agricultural era to the industrial era, and now to the information age. Knowledge is a basic input in the information age, no longer based on physical materials such as natural resources in the Agriculture era or heavy steam-powered machines in the industrial era. An unexpected part of the human evolution of the information age is when humans work purely with their minds and not their bodies. The creation of such a trend cannot be separated from the invention of computers, cellphones and the expansion of communication networks, especially through the internet, 
which makes the entire unit connected without being obstructed by boundaries or borders. The Internet is the second most important medium and its development in content dissemination, as well as the encouragement provided by social network users and mobile phone use (Young et al,2011).

Broadband internet technology is generally defined as a network or internet service that has a high transfer speed due to a large data lane width. Even though the data path that is provided for its users is very wide, broadband internet technology usually shares the broadband with surrounding users. However, if no one is using it, the user will fully use the broadband. Broadband internet technology or broadband is one of the transmission media technologies that support multiple frequencies, ranging from voice to video frequencies. Technology can carry a lot of signals by dividing the capacity (which is very large) into several channels bandwidth each channel operates at a specific frequency. In simple terms, the term broadband internet technology is used to describe a connection with a speed of $500 \mathrm{Kbps}$ or more (Gürtzgen et al,2021).

In a country's economy, broadband internet is starting to be felt to have an important role in a country's economy because, with the development of information technology, a country's economy has begun to show significant changes. Many things feel different and change compared to the way that was developed before. Nowadays distance and time are not a significant problem to support economic growth, various applications are created to facilitate it. Moreover, with the development of broadband internet today in almost all parts of the world, I would like to examine whether the advancement of broadband internet networks such as $1 \mathrm{G}, 2 \mathrm{G}, 3 \mathrm{G}$ and $4 \mathrm{G}$ LTE is more precisely the effect of $3 \mathrm{G}$ broadband internet on economic growth around the world (Jha \& Saha,2019). The internet has driven consumption through the online shopping trend. This encouragement of consumption through online shopping has boosted economic growth. And the encouragement of economic growth encourages increased public income.

\section{Research Methods and Materials}

This study aims to observe the growth impetus for internet users towards public consumption which further boosts people's income in Indonesia. To achieve this objective, data on internet user behaviour, consumption and GDP per capita were observed. This study uses the Quantitative Threshold Autoregressive method which is used to predict the behaviour of the data so that the relationship behaviour between the data can be seen. The hope is that knowing past behaviour data can be an indicator of decisions that can be taken in the future. In this study we used the autoregressive equation as follows:

$\mathrm{AR}_{(\mathrm{p})}=\mathrm{Y}_{\mathrm{t}}=\mathrm{c}+\Phi_{1} \mathrm{Y}_{\mathrm{t}-1}+\Phi_{2} \mathrm{Y}_{\mathrm{t}-2}+\ldots . .+\Phi_{\mathrm{p}} \mathrm{Y}_{\mathrm{t}-\mathrm{p}}+\mathrm{e}_{\mathrm{t}}$

Where AR is $\mathrm{Y}$ and $\mathrm{Yt}$ is $\mathrm{Y}$ from time to time in a time series which is influenced by $\mathrm{Yt}-1$ or $\mathrm{Y}$ from time to time in the past in period 1 and Yt-1 itself is also influenced by Yt-2 which is $\mathrm{Y}$ in the past in period 2 onwards which is influenced by et which is the error term for the time in the study period. This study focuses on secondary data sourced from world banks, including data on internet users, consumption and GDP per capita in Indonesia. With the econometric equation as follows:

$Y_{t}=\beta_{0}+\beta_{1} C_{t 1}+\beta_{2} I_{U_{2}}+e_{t}$ 
Where $\mathrm{Y}$ is a gross domestic product, $\mathrm{t}$ is a time period, $\beta$ is constant, $\mathrm{C}$ is consumption, $\mathrm{IU}$ is internet user and e is error term. All data are secondary data from world banks.

\section{Results and Discussion}

In analyzing the threshold variable, two estimates are used where the first estimate is the IU or Internet User variable as the threshold variable. Meanwhile, $\mathrm{C}$ or Consumption is a non-threshold variable. To see behaviour data when there is a change in human factors, namely health and education. For the second estimate, the opposite is done where the variable $\mathrm{C}$ or Consumption is non-threshold variables. Whereas IU or Internet User is a threshold variable. This is done to see the data behaviour when non-human variables, wherein this study there is a change in technology. The following is the results of the first estimation where the threshold variable is IU or Internet User, the non-threshold variable is Consumption :

GDP_PER_CAPITA $=(0.000115726250557 *$ INTERNET_USER $\quad+\quad 3027.17616131)$ $(-9.50391818756 \mathrm{e}-05 *$ INTERNET_USER 3999.43925949)*@LOGIT(0.00323766615889*(GDP_PER_CAPITA(-3)-1825.91299595)) 7.35904883536e-09*CONSUMPTION

The estimation results from the first estimate can be seen in table 1 below:

Table 1. Estimation Result

\begin{tabular}{|c|c|c|c|c|}
\hline Variable & Coefficient & Std. Error & t-Statistic & Prob. \\
\hline \multicolumn{5}{|c|}{ Threshold Variables (linear part) } \\
\hline INTERNET_USER & 0.000116 & $1.78 \mathrm{E}-05$ & 6.503129 & 0.0001 \\
\hline $\mathrm{C}$ & 3027.176 & 1211.531 & 2.498636 & 0.0315 \\
\hline \multicolumn{5}{|c|}{ Threshold Variables (nonlinear part) } \\
\hline INTERNET_USER & $-9.50 \mathrm{E}-05$ & $1.39 \mathrm{E}-05$ & -6.856558 & $\overline{0}$ \\
\hline $\mathrm{C}$ & 3999.439 & 942.9074 & 4.241603 & 0.0017 \\
\hline \multicolumn{5}{|c|}{ Non-Threshold Variables } \\
\hline & & & & \\
\hline CONSUMPTION & $-7.36 \mathrm{E}-09$ & $4.01 \mathrm{E}-09$ & -1.835712 & 0.0963 \\
\hline \multicolumn{5}{|l|}{ Slopes } \\
\hline SLOPE & 0.003238 & 0.001422 & 2.277131 & 0.046 \\
\hline & & & & \\
\hline \multicolumn{5}{|l|}{ Thresholds } \\
\hline THRESHOLD & 1825913 & 1173114 & 1556466 & 0 \\
\hline & & & & \\
\hline R-squared & 0.993756 & Mean dependent var & & 2805.471 \\
\hline Adjusted R-squared & 0.99001 & S.D. dependent var & & $1.08 \mathrm{E}+03$ \\
\hline S.E. of regression & 108.4365 & Akaike info criterion & & $1.25 \mathrm{E}+01$ \\
\hline Sum squared resid & $1.18 \mathrm{E}+05$ & Schwarz criterion & & 12.8462 \\
\hline Log likelihood & $-9.93 \mathrm{E}+01$ & Hannan-Quinn criter. & & 12.53721 \\
\hline F-statistic & 265.2572 & Durbin-Watson stat & & 2.41094 \\
\hline Prob(F-statistic) & 0 & & & \\
\hline
\end{tabular}

Source : Data world Bank Compiled 
It can be seen that the relationship between GDP per capita and Internet User is positive with a value of 0.000116 and 3027,176 for consumption. this means that an increase in internet users by $0.000116 \%$ can encourage consumption by $3027 \%$ with an increase in GDP per capita of $1 \%$. This is certainly a very strong impetus for economic growth. To determine the behaviour of Internet User data in encouraging consumption and per capita income, predictions of internet users and consumption of GDP per capita can be made in the following graph:

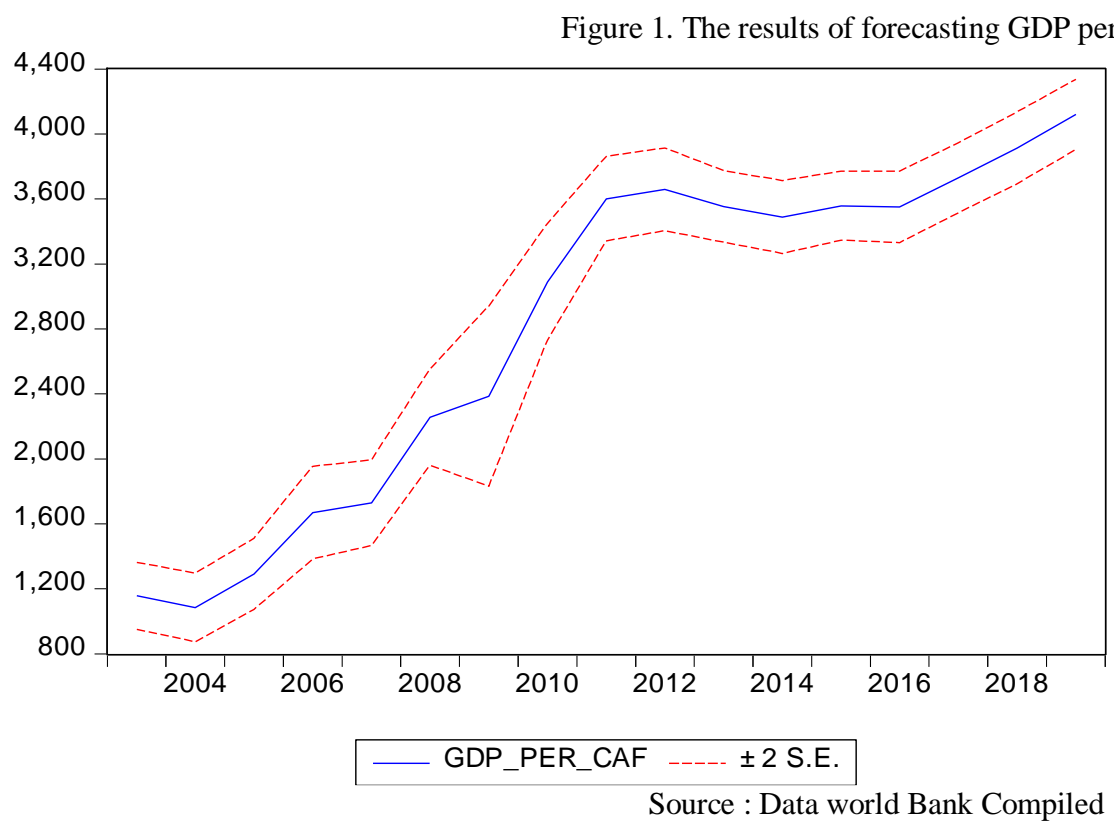

\begin{tabular}{|c|c|}
\hline \multicolumn{2}{|l|}{ Forecast: GDP_PER_CAF } \\
\hline \multicolumn{2}{|l|}{ Actual: GDP_PER_CAPITA } \\
\hline \multicolumn{2}{|l|}{ Forecast sample: 20002019} \\
\hline \multicolumn{2}{|l|}{ Adjusted sample: 20032019} \\
\hline \multicolumn{2}{|l|}{ Included observations: 17} \\
\hline Root Mean Squared Error & 88.34656 \\
\hline Mean Absolute Error & 69.13252 \\
\hline Mean Abs. Percent Error & 3.192178 \\
\hline Theil Inequality Coefficient & 0.014736 \\
\hline Bias Proportion & 0.008823 \\
\hline Variance Proportion & 0.028268 \\
\hline Covariance Proportion & 0.962909 \\
\hline Theil U2 Coefficient & 0.284043 \\
\hline Symmetric MAPE & 3.165723 \\
\hline
\end{tabular}

From the forecast results shown in Figure 1, it can be seen that the GDP per capita graph can be pushed very rapidly. This shows that technology inclusion has an impact on driving economic growth through consumption. From the estimation results, it can be seen that the impulse of internet users is on the demand side or the marketing side. This can be seen from the boost of internet users which is less than $0.001 \%$ which is able to encourage consumption of $3027 \%$. This means that there is virality in domestic sales or the same product is traded between consumers and the final consumer. This means that there are many trading businesses that have grown as a result of the internet revolution in Indonesia.

\section{Conclusions}

Internet users are the total internet users in Indonesia who are able to boost people's income as indicated by GDP per capita. Where the internet users' impulse towards consumption is very strong. This indicates a massive growth in business lines as a result of the Internet revolution in Indonesia, namely trading businesses that involve digital technology.

\section{References}

Chen-Wishart,M., Vogenauer,S.(2020).Contents of Contracts and Unfair Terms. London: Oxford University Press 
Dewi,F.Mahendrawathi,E.R.(2019).Business Process Maturity Level of MSMEs in East Java, Indonesia.Procedia Computer Science,161(1),1098-1105. https://doi.org/10.1016/j.procs.2019.11.221

Gürtzgen,N., Diegmann,A., Pohlan,L., Berg,G.J.v.d.(2021).Do digital information technologies help unemployed job seekers find a job? Evidence from the broadband internet expansion in Germany.European Economic Review,132(1).1-13.https://doi.org/10.1016/j.euroecorev.2021.103657 Jha,A., Saha,D.(2019).Techno-commercial feasibility analysis of 4G mobile services in India.IIMB Management Review,31(2).182-199. https://doi.org/10.1016/j.iimb.2019.03.007

Liu,J., Li,Y., Lu,Y., Fu,X., Yan,S.(2020).Research on the influence factors of ubiquitous power Internet of things for promoting consumption of wind power based on fuzzy G1-ISM in China.International $\begin{array}{lllll}\text { Journal of } & \text { Electrical } & \text { Power } & \text { Energy } & \text { Systems,121(1).1-13. }\end{array}$ https://doi.org/10.1016/j.ijepes.2020.106124

Young,J., Brown,A., Carr,L., Korte,J., Modesitt,S.(2011).Television and Internet sources of information negatively associated with human papillomavirus vaccination among college-age women. Gynecologic Oncology, 120 (1),124-130.https://doi.org/10.1016/j.ygyno.2010.12.298 